logos_i_ethos_2014_1_(36), s. 73-85

\title{
Michał Warchala
}

\section{Romantyzm i narodziny myśli postsekularnej}

Współczesny postsekularyzm bywa często postrzegany jako „powrót religii” do późnonowoczesnego (bądź ponowoczesnego) dyskursu, jej triumf nad laicką nowoczesnością i zarazem symptom wyczerpania tej ostatniej. Trzeba przyznać, że taka interpretacja jest nader kusząca, a przemawiać za nią może choćby to, iż myśl postsekularna inspiruje się poniekąd przeprowadzaną

Michał Warchala - historyk idei, tłumacz. Wykładowca Uniwersytetu Pedagogicznego w Krakowie. Autor m.in. książki Autentyczność $i$ nowoczesność. Idea autentyczności od Rousseau do Freuda (Kraków 2006). w socjologii religii krytyką teorii sekularyzacji jako „nieuchronnej” cechy nowoczesności - krytyka ta kładzie nacisk właśnie na trwanie religii czy wręcz jej renesans, na „desekularyzację” świata, by użyć określenia Petera Bergera, jednego z głównych krytyków tradycyjnych tez o sekularyzacji ${ }^{1}$.

W niniejszym tekście chciałbym jednak zaproponować inną lekturę postsekularyzmu - jako nie tyle kapitulacji nowoczesności wobec sił bardziej od niej pierwotnych, ile raczej przejawu wewnętrznej refleksyjnej pracy, swoistej „autokorekty” zachodniej modernitas, której celem jest ograniczenie „niezamierzonych konsekwencji” własnego rozwoju. Jedną z najważniejszych spośród nich jest analizowana przez Jürgena Habermasa w sławnym eseju Wierzyć i wiedzieć (2001) opozycja między wojującym sekularyzmem, którego naukowy humanizm w istocie przeciera szlak dla kompletnie już odhumanizowanego naturalizmu, a równie agresywnym fundamentalizmem religijnym, który, występując w imię rzekomej czystości tradycji, nie uświadamia sobie własnej zależności od 
na wskroś nowoczesnego myślenia ${ }^{2}$. Postsekularyzm to zatem nie tyle powrót religii wypartej przez nowoczesność, ile raczej nieco paradoksalne połączenie dwóch założeń: pierwsze $\mathrm{z}$ nich głosi, że religia objawienia, traktowana jako struktura zbudowana na bazie zwartego systemu dogmatycznego skodyfikowanego w teologii, została ostatecznie pogrzebana przez oświeceniową krytykę i może być już tylko martwą, coraz bardziej ciążącą i opresyjną skorupą. Drugie założenie sprowadza się do konstatacji, że religijne pojęcia i intuicje są mimo wszystko na tyle cenne i odsłaniają na tyle szeroki horyzont znaczeń, że warto je zachować, włączając w nową formę, która posłuży z kolei jako kontra dla bardziej

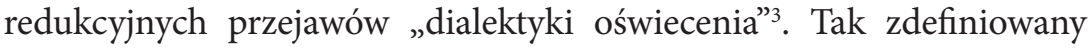
postsekularyzm, choć może wydawać się nowością w późnonowoczesnym pejzażu, nie jest jednak w istocie czymś całkowicie oryginalnym. Podstawowe założenie niniejszego tekstu głosi, że myślenie postsekularne, jako specyficzna autokorekta nowoczesności, towarzyszy jej od samych początków. Jego pierwszą postacią jest „religia romantyczna”, specyficzny sposób wykorzystania religijnych i teologicznych konceptów i symboli obecnych w brytyjskim High Romanticism oraz niemieckiej frühe Romantik, a więc u autorów takich jak William Blake, William Wordsworth, Friedrich Schlegel czy Novalis - tę romantyczną konstelację postaramy się tu pokrótce opisać. Romantyczne wątki postsekularne odżywają ponownie w kolejnej konstelacji, która powstaje w okresie modernizmu: tworzą ją, z jednej strony, socjologia religii Maxa Webera, stanowiąca swoisty krytyczny rozrachunek z oświeceniowymi próbami „zniesienia” religii w nauce - i stanowiąca punkt wyjścia dla „politycznej teologii” Carla Schmitta czy Karla Löwitha, z drugiej strony zaś nurt filozofii żydowskiej wywodzący się od Hermanna Cohena i kontynuowany później przez Franza Rosenzweiga i Waltera Benjamina. Ten ostatni

2 J. Habermas, Wierzyć $i$ wiedzieć, tłum. M. Łukasiewicz, „Znak”, 2002, nr 9 (568), por. także książkę tegoż Między naturalizmem a religią, przeł. M. Pańków, Warszawa 2012.

Takie określenie postsekularyzmu wykorzystuje i rozwija pewne intuicje zawarte we wspomnianym wyżej eseju Habermasa, który z kolei wyraźnie nawiązuje do wywodów Theodora W. Adorna, zawartych np. w tekście Rozum i objawienie, tłum. A. Lipszyc, „Kronos”, 2007, nr 1, s. $28-33$. 
można traktować jako próbę znalezienia trzeciej drogi albo „trzeciego języka” ${ }^{4}$ pomiędzy postoświeceniową filozofią a religią i teologią. Nieprzypadkowo funkcję pośrednika pełni tu - zwłaszcza na przykład w Rosenzweigowskiej Gwieździe zbawienia - niemiecki romantyzm.

Owa druga konstelacja postsekularna już bezpośrednio inspiruje postsekularystów współczesnych, takich jak przywoływany wcześniej Habermas oraz Slavoj Zizek czy Georgio Agamben - dla nich odniesienia do Webera, Benjamina czy Schmitta mają charakter absolutnie podstawowy. W ten sposób historia idei ukazuje nam genealogię współczesnej myśli postsekularnej i jednocześnie odmienną niż dotychczasowa strukturę nowoczesności ${ }^{5}$, w której trzeci biegun w postaci postsekularyzmu zajmuje istotne miejsce obok dwójki wielkich antagonistów: religii i sekularyzmu, „wiary” i „rozumu”.

\section{Ironia i natura}

Próbując opisać zjawisko postsekularnej religii romantycznej, posłużymy się dobrze znaną i od dawna już stosowaną do opisów romantyzmu dychotomią ${ }^{6}$. Z jednej strony zatem romantyzm zawiera w sobie bez wątpienia pierwiastek demonicznego „nienasycenia”, którego najbardziej adekwatnym wyrazem jest pojęcie wyobraźni poetyckiej rozwijane przez Williama Blake’a czy koncept ironii romantycznej skodyfikowany

4 To wyrażenie z Derridiańskich Acts of religion do filozofii Hermanna Cohena zastosował Adam Lipszyc w niepublikowanym tekście Inne źródło: racjonalność i objawienie w ostatniej ksiażce Hermanna Cohena.

Oczywiście dokładne prześledzenie wszystkich tych związków idei jest niemożliwe w dość wąsko zakreślonych ramach niniejszego tekstu. Zainteresowanego czytelnika można odesłać do innych publikacji autora, bardziej szczegółowo analizujących te wątki: Co to jest postsekularyzm. (Subiektywna) próba opisu, „Krytyka Polityczna”, 2007, nr 13 oraz Postsecular constellations in modernity (tekst wystąpienia na konferencji „Theology and Social Sciences” zorganizowanej przez Centrum Myśli Jana Pawła II; dostępny na stronie http://www.centrumjp2.pl/node/5645/Papers (10.04.2012).

$6 \quad$ Stosuje ją np. Arthur Lovejoy w klasycznym eseju On the discrimination of romanticisms zamieszczonym w zbiorze Essays on the history of ideas, Baltimore 1948. Por. też interesującą polemikę René Welleka Pojęcie romantyzmu w badaniach literackich (tłum. I. Sieradzki, [w:] tenże, Problemy i pojęcia nauki o literaturze, Warszawa 1979). 
przez Friedricha Schlegla (posługującego się w tym wypadku dialektycznymi narzędziami dostarczonymi przez Johanna G. Fichtego) jako unendliches Schweben, wieczna „oscylacja”, ruch podmiotu ustanawiającego siebie i świat. Romantyzm to bunt i oderwanie od zastanej rzeczywistości, wyjście poza wszelkie ustalone dotąd kategorie, a zarazem pragnienie ogarnięcia całości bytu w jednym ruchu profetycznej jaźni. Z drugiej strony jednak romantyzm to także nostalgia za jednością i harmonią utraconą wraz z zawirowaniami nowoczesności najlepiej wyrażająca się w ciążeniu ku - skądinąd rozmaicie rozumianej - naturze jako odwiecznemu domostwu człowieka, z którego ten ostatni został wygnany i do którego pragnie powrócić. „Wo geh’n wir denn hin? Immer nach Hause” („Dokąd zmierzamy? Wciąż do domu”), mówi bohater Heinricha von Ofterdingen Novalisa, a to stwierdzenie doskonale opisuje końcową fazę owego charakterystycznie romantycznego cyklu: jedności-wygnania-powrotu do „naszego wielkiego domu”, jakim jest natura. Ten powrót-pojednanie może mieć różnoraki charakter - od pełnego powtórnego roztopienia się w boskiej jedności natury do zaledwie dynamicznego stanu ,jedności przeciwieństw”, w którym autonomia człowieka jako istoty „sztucznej” i w sposób nieredukowalny już wyalienowanej z naturalnego bytu zostaje po części zachowana. Nawet jednak przy takim ograniczeniu powtórna naturalizacja człowieczeństwa stanowi dla romantyków pokusę, której wielu spośród nich nie potrafi się oprzeć.

Postsekularna „religia romantyczna” w jej rozmaitych odmianach mieści się w obszarze wyznaczonym przez te dwa bieguny - nazwijmy je umownie „demonicznością” i „naturalizmem”. W niniejszym tekście możemy, rzecz jasna, szkicowo omówić jedynie kilka spośród tych odmian.

\section{Nieustająca pokusa naturalizmu}

Wypada zacząć od bieguna naturalistycznego, to on bowiem stanowi bezpośredni punkt styczności między romantyzmem a poprzedzającą go formacją oświeceniową. Najbardziej charakterystyczną wersję "religii natury” przedstawia Jean J. Rousseau w Wyznaniu wiary wikarego sabaudzkiego (stanowiącego część Emila) i to on odpowiada 
przede wszystkim za zaszczepienie romantykom tytułowej „naturalistycznej pokusy”. Religia natury stanowi konsekwencję całej filozoficznej antropologii Rousseau, opartej na przeciwstawieniu autentyczności natury i nieautentyczności człowieka cywilizowanego, który, żyjąc w społeczeństwie pozoru i kłamstwa, zmuszony jest do nieustannego udawania. Kultura i cywilizacja narzucają refleksyjność, a ta z kolei tworzy wewnętrzne podwojenie, dédoublement, uniemożliwiające osiągnięcie niezapośredniczonego „poczucia istnienia” (sentiment de l'existence), stanowiącego fundament egzystencji autentycznej. Od debiutanckiej Rozprawy o naukach i sztukach poprzez Rozprawę o nierówności i Wyznania aż po Przechadzki samotnego marzyciela, Rousseau będzie poszukiwał owego poczucia, zwalczając - z coraz bardziej paranoiczną zaciekłością - prześladujące go fałszywe wizerunki samego siebie. Zwieńczeniem tych poszukiwań będzie dokonane w Przechadzkach samotnego marzyciela paradoksalne odkrycie, że warunkiem „odzyskania siebie”, niezapośredniczonego odczuwania własnego Ja jest ucieczka w czystą zewnętrzność, „roztopienie” intelektu i wyobraźni (nieustannie podsuwających fałszywe mniemania i generujących refleksyjne dédoublement) w potoku niezależnych od Ja zewnętrznych doznań. W Piątej przechadzce Rousseau, leżąc w łódce i zatapiając jaźń w szumie przepływającej wody, dostępuje właściwej ekstazy poczucia istnienia ${ }^{7}$. Ekstaza ta ma wyraźne cechy religijne, a rządząca nią paradoksalna logika zostanie raz jeszcze zastosowana w Wyznaniu wiary wikarego sabaudzkiego, gdzie Bóg sprowadzony jest do czystej zewnętrzności natury, sterującej bezpośrednio ludzkimi odruchami ${ }^{8}$.

J. J. Rousseau, Przechadzki samotnego marzyciela, tłum. M. Gniewiewska, Warszawa 1967, por. zwł. s. 26-30.

Tenże, Wyznane wiary wikarego sabaudzkiego, [w:] Emil, czyli o wychowaniu, tłum. J. Husarski, Wrocław 1955, t. 2, s. 98 oraz 110-111. Nie mając tu możliwości przeprowadzenia szczegółowej analizy Wyznania wiary, mogę jedynie odesłać czytelnika do swojego tekstu Religia romantyczna. Kilka głównych wątków opublikowanego w: „Kronos”, nr 1/2007, a także do książki Autentyczność i nowoczesność. Idea autentyczności od Rousseau do Freuda (Kraków 2006, s. 35-77), gdzie szczegółowo rozwijam sygnalizowane tu wątki. Por. też znakomitą analizę Wyznania wiary dokonaną przez Paula de Mana w jego Alegoriach czytania (tłum. A. Przybysławski, Kraków 2004, s. 264-292). 
Ten Roussowski naturalizm wraz z jego odniesieniami do sfery sacrum stanowił dla romantyków niemałą pokusę - mniej lub bardziej bezpośrednie świadectwa zauroczenia nim znajdziemy u twórców skądinąd tak różnych jak Friedrich Hölderlin, William Wordsworth czy Percy Shelley ${ }^{9}$. Z punktu widzenia romantyków ma on kilka zalet. Przede wszystkim odnosi wyobrażenie Boga bezpośrednio do problemu jednostkowej autentyczności, ucieczki od niepokojów kultury i cywilizacji ku naturze traktowanej jako warunek niezakłóconej relacji z samym sobą i autentycznego istnienia. Przekonanie o „nienaturalności” religijnej ortodoksji, obciążonej balastem oszukańczych społecznych rytuałów to pogląd, który romantycy dziedziczą po oświeceniu i który na swój sposób wykorzystują. Roussowskie "poczucie istnienia” to dla nich coś, co ów balast likwiduje, pozwala odnaleźć swego rodzaju „stan łaski”, w którym możliwa jest prawdziwa poiesis, twórczość wykraczająca poza estetykę ku realnemu przekształceniu świata, tworzeniu nowej rzeczywistości. Po drugie zaś, Rousseau to twórca rewolucyjny, prawdziwy ojciec zrywu z 1789 roku, który dla wszystkich właściwie romantyków - od Schlegla i Blake’a aż po Novalisa, Wordswortha i Coleridge'a - był, przynajmniej do pewnego czasu, niemal synonimem ziemskiej apokalipsy, wydarzeniem zapowiadającym powstanie tysiącletniego królestwa wolności i równości, w którym człowiek miał wreszcie zacząć żyć inaczej, po Roussowsku właśnie, w zgodzie z naturalnymi popędami, bez niedoli związanej z egoizmem, miłością własną i fałszywymi wyobrażeniami alienującymi go od samego siebie ${ }^{10}$.

Po ekscesach terroru jakobińskiego eschatologiczne nadzieje zaczęły gasnąć i podobnie też zmieniał się stosunek do Rousseau i jego religii natury. Między naturą a wyobraźnią coraz częściej dostrzegano

9 Najlepszą chyba analizę przenikania Rousseowskich motywów do romantyzmu brytyjskiego i niemieckiego znajdziemy u Paula de Mana w jego The Gauss Seminar of 1967 zamieszczonym w książce Romanticism and contemporary criticism (Baltimore 1993), a także w eseju The image of Rousseau in the poetry of Hölderlin z książki The rhetoric of romanticism, New York 1984, s. 19-46.

10 Por. analizy M. H. Abramsa z jego klasycznej już książki Natural supernaturalism. Tradition and revolution in romantic literature, New York 1971, zwł. rozdz. 6. Na temat oddziaływania Rousseau na brytyjskich romantyków por. także pracę Edwarda Duffy'ego Rousseau in England (Berkeley 1979). 
niemożliwe do rozwiązania napięcie, dla którego „miejscem” jest poetycki idiom. Eschatologiczne przeczucia ulegają uwewnętrznieniu, a ich nośnikiem staje się wyobraźnia, oddalająca się coraz bardziej od natury - nawiązywanie łączności między nimi będzie głównym celem poezji. Emblematyczna w tym aspekcie jest twórczość Wordswortha: jego poetycka praktyka to przede wszystkim nieustanny wysiłek takiego opisu zwyczajnych przedmiotów i zdarzeń, by oddać aurę intimations of immortality, „przeczuć nieśmiertelności”, którymi wyobraźnia nasyca otaczającą rzeczywistość. Każdy wiersz staje się przestrzenią, w której apokaliptyczny przebłysk wyobraźni zostaje niejako „spacyfikowany” w narracji o rzeczach. Tę „kontrolowaną” czy „powtrzymywaną” apokalipsę doskonale widać w takich wierszach, jak Tintern Abbey albo Resolution and Independence, gdzie drobne epizody, elementy pejzażu albo napotkani w trakcie przechadzki ludzie „uruchamiają” w umyśle przeczucia rzeczy ostatecznych ${ }^{11}$. To, co tylko naturalne i zwykłe, okazuje się naładowane ponadnaturalną treścią - umysł pod maską naturalności odnajduje własne apokaliptyczne obrazy.

Inna, bardziej subtelna, postać oświeceniowej religii natury, która wywarła istotny na romantyków, wiąże się z odnowieniem w XVII i XVIII wieku ezoterycznej mitologii Egiptu jako tajemnego źródła "prawdziwego" monoteizmu, wytyczającego szlak dla judaizmu i chrześcijaństwa. Monoteizm ten miał być w zasadzie syntezą "religii natury” i para-gnostyckiej „religii rozumu” - jego istotą była bowiem cześć oddawana naturze a zarazem wiedza o jej tajemnicach uzyskiwana na drodze kolejnych wtajemniczeń i zapisana w egipskich hieroglifach. Zgodnie z ideologią zachodnioeuropejskiej masonerii, dla której ów egipski mit był istotnym fundamentem, to właśnie ta pradawna wiara miała stać się nową religią ludzkości detronizującą chrześcijaństwo. Taką wizję

11 Motyw „powstrzymywanej apokalipsy” u Wordswortha znakomicie omawia Geoffrey Hartman w: Wordsworth's poetry 1787-1814, New Heaven-London 1971. 
przedstawia między innymi Gotthold Ephraim Lessing w swoim Wychowaniu rodzaju ludzkiego ${ }^{12}$. Po okresie dzieciństwa symbolizowanego przez judaizm i młodości, którą stanowi chrześcijaństwo, ludzkość w wieku dojrzałym może wreszcie wejść w fazę religii bez Boga i objawienia, gdzie nowym bóstwem, przedmiotem wiary i kultu będą filozoficzne zasady moralne, których źródłem jest natura.Podobne wizje odnajdziemy u Johanna Gottfrieda Herdera, Johanna Georga Hamanna, a nawet u Kanta, choć w jego przypadku antynaturalistyczny charakter, w jaki wyposaża swoją koncepcję prawa moralnego, nie pozwala na tego rodzaju łatwe godzenie natury, moralności i objawienia.

Centralnym symbolem tej naturalistycznej syntezy religii i filozofii jest słynny zasłonięty posąg bogini Izydy przedstawiającej Naturę, który, zgodnie z ezoterycznym przekazem, miał znajdować się w egipskiej świątyni w Sais. Milcząca kontemplacja posągu miała być ostatnią fazą wtajemniczenia w religię natury. Motyw kultu z Sais pojawia się u najważniejszego z twórców stojących na pograniczu oświecenia i romantyzmu, czyli Fryderyka Schillera (w jego rozprawie Die Sendung Moses). Dla niego, jak wyraża to zwięźle Jan Assmann, „,najważniejszym odkryciem było utożsamienie boga filozofów, boga rozumu i objawienia z najgłębszą i najbardziej wzniosłą tajemnicą egipskich misteriów”"13, z Naturą rozumianą jako bezcielesna jednocząca siła, przenikająca wszystko, co żyje. W swojej dojrzałej twórczości Schiller wmontowuje jednak tę ezoteryczną religię natury w dialektyczny schemat historiozoficzny (wyłożony m.in. w Listach o estetycznym wychowaniu człowieka), będący bardziej rozwiniętą wersją oświeceniowej egzegezy Biblii dokonanej przez Lessinga, a zarazem zapowiadający już majestatyczne syntezy Hegla czy Schellinga. Religia natury to wedle Schillera nowa szczęśliwa jedność, dopełnienie historii ludzkości, która we właściwym sensie tego słowa rozpoczęła się wraz z wygnaniem z raju. To wtedy między człowiekiem

12 G. E. Lessing, Wychowanie rodzaju ludzkiego, przeł. A. Sowiński, [w:] tenże, Dzieła, t. 3, Warszawa 1959.

13 J. Assmann, Moses the Egyptian. The memory of Egypt in Western monotheism, London-Cambridge Mass. 1997, s. 126. 
a naturą powstała przepaść, wtedy też człowieczeństwo uległo fragmentacji, wytwarzając z jednej strony fenomenalną sferę popędów naturalnych i „noumenalny” obszar prawa moralnego. Ta fragmentacja, która jeszcze u Kanta pozostaje nienaruszalna, zgodnie z wizją Schillera ma zostać zlikwidowana w nowej zbawczej syntezie, której medium stanowi wymiar estetyczny ze swoim Spieltrieb, popędem gry, łączącym w sobie naturalność oraz posłuszeństwo prawu moralnemu - w tej syntezie natury przenikniętej prawem moralnym człowiekowi ukazuje się właściwy wymiar nieskończoności. W ten sposób wygnanie $\mathrm{z}$ raju, będące z pozoru upadkiem i dramatem człowieka, okazuje się w końcu felix culpa, szczęśliwym grzechem, początkiem drogi ku emancypacji i wolności.

Jak wskazuje Meyer H. Abrams, ten Schillerowski schemat był później w niemieckim i brytyjskim romantyzmie powielany nieskończoną ilość razy, tworząc leitmotiv tego, co nazywamy tu religią romantyczną, a co Abrams określa sugestywnym (zapożyczonym od Thomasa Carlyle’a) mianem natural supernaturalism ${ }^{14}$. Rajskie, „dziecięce” bytowanie w łączności z naturą, później separacja i upadek, a w końcu powrót do natury już na wyższym poziomie, gdzie króluje wolność, a człowiek otwiera się na nieskończoność, choć zarazem w jakimś sensie powraca też do stanu rajskiego dzieciństwa. Te dwie postaci ruchu - powrót do pierwotnej wspólnoty z bytem i odtworzenie tej wspólnoty w innej postaci na wyższym poziomie - są tu ze sobą splecione bardzo ściśle, ale siłą rzeczy istnieje między nimi pewne niemożliwe do usunięcia napięcie. Czy powrót do źródła jest możliwy? Czy „dom”, do którego wracamy, jest tym samym domem, z którego wyszliśmy, a może długotrwałe wyobcowanie sprawiło, że nigdy już nie pozbędziemy się naddatku refleksyjności? Może źródło już nie istnieje, a pojednanie jest możliwe jedynie w refleksyjnym medium dialektycznie ukształtowanej samoświadomości, bo zgodnie ze słynną formułą Hegla z jego Encyklopedii nauk filozoficznych „tylko włócznia, która zadała ranę, może ją uzdrowić”... To napięcie funduje romantyczny postsekularyzm z całą jego wewnętrzną dynamiką. 


\section{Epifania podmiotowości absolutnej - przypadek Blake’a}

Aby zobaczyć, czym jest religia romantyczna w swej najbardziej radykalnej, profetycznej i „demonicznej” zarazem formie, trzeba sięgnąć do twórczości Williama Blake’a. Autor Jerusalem i The Four Zoas to idealny niemal wzór romantycznego proroka-buntownika, religijnego nonkonformisty walczącego na dwa fronty: przeciw strupieszałej, jego zdaniem, starej ortodoksji i próbującej ją zastąpić ortodoksji nowej, „oświeconej” i znaturalizowanej - te dwie formy religijne na tyle zresztą zdaniem Blake’a zlały się ze sobą, że niekiedy trudno je od siebie odróżnić.

Nie sposób opisać tu, rzecz jasna, wszystkich wątków, które w jego skomplikowanym systemie poetyckiej spekulacji wiążą się ze wspomnianą relacją. Harold Bloom zwraca uwagę, że sam koncept natury jest u Blake'a konceptem najbardziej ambiwalentnym ${ }^{15}$. W "geografii” jego poetyckiego świata, która, dodajmy od razu, jest równocześnie antropologią i psychologią, natura stanowi zarazem przedsionek Edenu, raju wyobraźni, gdzie króluje przebóstwiony człowiek-stwórca, jak i przedsionek krainy Ulro symbolizującej panowanie śmierci, wieczną martwotę zaskorupiałych form. Natura, występująca zwykle pod postacią Beulah, „ziemi poślubionej” z księgi proroctw Izajasza to symbol płodności w dwojakim sensie: niższym, czysto wegetatywnym, gdzie chodzi o reprodukowanie egzystencji bezrefleksyjnej, „uśpionej”, oraz wyższym, który siłę przekuwa w sens, dostarczając energii poetyckiej wyobraźni projektującej nowy świat. Te dwa aspekty natury to bodaj najważniejsze z Blake’owskich contraries, równoważących się przeciwieństw, które nigdy nie dostępują heglowskiego zniesienia, Aufhebung w wyższej syntezie. Natura okazuje się niezbędna z punktu widzenia mitopoetyckiego projektu, ale może też być dla niego śmiertelną pułapką. Jest zarazem wspomnieniem rajskiej pełni, która antycypuje przyszłe panowanie przebóstwionego człowieka, jak i kwintesencją stworzenia będącego zarazem upadkiem, który nieśmiertelność zamienił w nędzę materialnej egzystencji.

15 Por. H. Bloom, The visionary company, Ithaca-London 1971, s. 20. 
Mając w pamięci ten quasi-dialektyczny charakter myślenia Blake’a, łatwiej ująć subwersywny element jego krytyki religii. Ta krytyka kieruje się w pierwszym rzędzie przeciwko deizmowi, który zdaniem angielskiego poety do głębi przeniknął tradycyjną ortodoksję. Blake kieruje przeciw współczesnej sobie religii dwa komplementarne, choć w swej istocie przeciwstawne zarzuty. Po pierwsze, jest ona systemem oddającym pierwotną boską energię w niewolę intelektu, który stara się ją skierować ku celom niezgodnym z jej autonomiczną naturą. Ten aspekt w mitologii Blake’a reprezentuje postać Urizena, tytana, który w świecie po upadku buduje własne królestwo niewoli i śmierci ${ }^{16}$. Jest ono skrzyżowaniem organizmu i maszyny, królestwem „zapomnienia, głupoty i konieczności”. Panują w nim prawa skrojone według jednolitej miary, regulujące wszystkie aspekty egzystencji upadłej ludzkości i zapisane w „stalowych księgach”17.

Religia pełni określoną funkcję w wszechogarniającym systemie praw. Blake opisuje ją przy pomocy metafory „sieci” (net), która krępuje ludzkie pragnienie. Religia wynika z uczucia litości (pity), która dla Blake’a jest niejako pragnieniem zwróconym przeciw samemu sobie, złośliwą parodią boskiej energii nietworzącą niczego wartościowego, budującą jedynie ochronne bariery ${ }^{18}$.

Z drugiej strony nowa odmiana tyrańskiej ortodoksji, deistyczna religia naturalna, zamykając boskość w naturze, sprowadza twórczą energię jedynie do poziomu wegetatywnego, poziomu wiecznej reprodukcji tych samych form. W aspekcie ludzkiego pragnienia religia naturalna wytwarza sprzeczność: ponieważ, jak zauważa Blake w krótkim

16 „Oto cień grozy się wzniósł | Pośród Wieczności! Nieznany, bezpłodny | Zamknięty w sobie, wszystko odpychający. Jakiż Demon | Tę wstrętną pustkę ukształtował, | Próżnię, która przeraża duszę? Niektórzy powiadali: | „To Urizen”. Lecz nieznana, odosobniona, | Zaczajona, tajemna, mroczna moc się kryła" (cyt. w przekł. Z. Kubiaka: Księga Urizena, [w:] Twarde dno snu. Tradycja romantyczna w poezji języka angielskiego, Warszawa 2002, s. 132).

17 Tamże, rozdz. 2, wers 34-40, s. 134; „Prawa pokoju, miłości, jedności, | Litości, współczucia, przebaczenia. | [...] Jedno przykazanie, radość jedną, tęsknotę jedną, | Jedną klątwę, jedno brzemię, jedną miarę".

18 Tamże, rozdz. 8, wers 18-21, s. 146; „Nic, nawet skrzydła ognia, nie mogło rozerwać | Owej sieci - tak mocne jej sznury, | Tak ciasne sploty, tak zwikłane, | Jak zwikłane są zwoje człowieczego mózgu.| I wszyscy ją Siecią religii zwali”. 
fragmencie poetyckim zatytułowanym There is no natural religion, pragnienie to „jest nieskończone”, jego obiekt musi być również czymś nieskończonym; tymczasem religia naturalna sprowadza człowieka do poziomu wegetatywnego, niszcząc tym samym jego istotę ${ }^{19}$.

Istnieje jednak droga wyjścia z zaklętego kręgu religii naturalnej i Urizenicznej przemocy rozumu. Zbawienie jest możliwe za sprawą tour de force wyobraźni, dialektycznego wglądu, który pod pewnymi względami jest dokładną odwrotnością Heglowskiej drogi rozumu. W „nauce o doświadczeniach świadomości” konkretna podmiotowość musi umrzeć, by wkroczyć na tę drogę - śmierć jest tu pozbyciem się wszelkiej faktyczności, wszelkich empirycznych pragnień. Wtedy można dostrzec, że są one niczym, a osnowę rzeczywistości tworzy uniwersalny rozum. U Blake’a zbawczy wgląd w istotę rzeczy polega na odkryciu, że rozumowe formy są w istocie tworem ludzkiego pragnienia. To powoduje, że zarówno rozumowe prawa, jak i religijne ograniczenia stają się "plastyczne” i podatne na zmianę. Wyobraźnia będąca dla Blake’a swoistą sublimacją pragnienia okazuje się wtedy zasadniczym „ontologicznym” czynnikiem, który kształtuje rzeczywistość. W apokaliptycznym poemacie Jerusalem wyobraźnia wznosi się do poziomu human form divine - następuje odzyskanie utraconej mocy, która w wynaturzonej formie religii Urizena zwracała się przeciw ludzkości. Pragnienie zyskuje pełnię, staje się siłą twórczą, która może kształtować nowy świat - jej symbolem jest Albion, człowiek przebóstwiony, obdarzony pełnią sił twórczych.

\section{Bibliografia}

1. Abrams M. H., Natural Supernaturalism. Tradition and Revolution in Romantic Literature, New York 1971.

2. Adorno T. W., Rozum i objawienie, tłum. A. Lipszyc, „Kronos”, 2007, nr 1, s. $28-33$.

19 W. Blake, There is no natural religion, [w:] The complete poetry and prose of William Blake, ed. D. V. Erdman, New York 1988, s. 2. 
3. Assmann J., Moses the Egyptian. The Memory of Egypt in Western Monotheism, London-Cambridge Mass. 1997.

4. Blake W., Ksiega Urizena, [w:] Twarde dno snu. Tradycja romantyczna w poezji języka angielskiego, tłum. Z. Kubiak, Warszawa 2002.

5. Blake W., There is No Natural Religion, [w:] The Complete Poetry and Prose of William Blake, ed. D. V. Erdman, New York 1988.

6. Bloom H., The Visionary Company, Ithaca-London 1971.

7. Habermas J., Wierzyć i wiedzieć, tłum. M. Łukasiewicz, „Znak”, 2002, nr 9 (568).

8. Hartman G., Wordsworth's Poetry 1787-1814, New Heaven-London 1971.

9. Rousseau J. J., Przechadzki samotnego marzyciela, tłum. M. Gniewiewska, Warszawa 1967.

10. Rousseau J. J., Wyznane wiary wikarego sabaudzkiego, [w:] Emil, czyli o wychowaniu, tłum. J. Husarski, Wrocław 1955. 